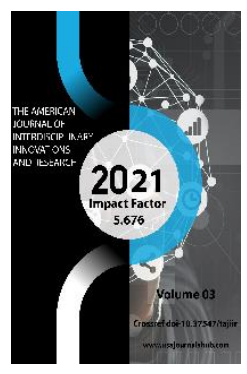

\title{
Mahallabay System Of Work: Organizational Mechanisms And Preliminary Results (On The Example Of Samarkand Region)
}

Rafeev Davron Rafeevich

Candidate Of Economic Sciences, Docent, Samarkand Institute Of Economics And Service, Uzbekistan

\section{ABSTRACT}

The article discusses the mechanism, content and preliminary results of the organization of the system of "mahallabay" in our country.

\section{KEYWORDS}

Mahallabay system of work, mechanism, permanent representatives, management office, coordination group, growth points.

\section{INTRODUCTION}

The President of the Republic of Uzbekistan visited Fergana region on February 4-5, 2021 to get acquainted with the development of the regions, major projects, dialogue with the population . During the visit, the head of state outlined the tasks of socio-economic development of the region, improvement of living conditions in the mahalla system .

It was also noted that due to employment and entrepreneurship development, it is necessary to focus on reducing poverty, to study and solve problems in the lives of every 
neighborhood, every family, every citizen , to introduce a new system to increase employment and income.

The term mahalla, which is actively used in our lives today, has a social significance and is considered as an effective mechanism for reducing poverty, solving employment problems, in short, solving today's hot problems. Therefore, neighborhood work is not just a term, it is a whole, holistic and perfect system.

\section{LITERATURE REVIEW}

The term "Mahallabay" operating system, its mechanism has not yet been studied and analyzed in any economic literature. From an economic point of view only, terms such as "ishbay"(workly) or "soatbay" (hourly) in the economic sense have been used a lot in our daily lives. At present, some economists and deputies have expressed their views on the system, its content and effectiveness. For example, financier Otabek Bakirov said that " he tries to deliver any product or service to the buyer, and in this sense, going to the neighborhood means that the banks will deliver the product to potential customers living in the neighborhood ." Banking services are covered by the most simple and direct way to distance services. Although we have never seen Mahallabay in history, this is one of the models ${ }^{1}$. Oliy Majlis deputy Daniyar Ganiev

\footnotetext{
1 Expensive mechanism or temporary effect.

Thoughts on the neighborhood performance system. Uzbekistan TV channel. Daily news. March 2, 2021

${ }^{2}$ Neighborhood processing system. Uzbekistan 24 TV channels . Analysis . March 4, 2021
}

noted that the Mahallabay system will work in the short term, but it should not exceed this limit'.

Currently, the main normative document related to the introduction of the "Mahallabay" system is " Methodological manual on the work carried out by the bank employee, sector management office and coordination groups attached to the mahalla in the organization of the mahalla system in districts and cities. ". 3

\section{RESEARCH METHODOLOGY}

Since the purpose of the study was to directly and indirectly determine the mechanism of the "mahalla" system of work and the factors affecting it, economic theory, the mechanism of market economy, statistical methods, inventory methods were used in its coverage.

\section{ANALYSIS AND RESULTS}

During his visit to Khorezm region on December 12-13, 2020, President Islam Karimov put forward the "idea of the chairmanreformer of the mahalla" and stressed the need to organize the activities of each ministry, department and organization in the mahalla.

Today, this system is being introduced into our lives.

\footnotetext{
${ }^{3}$ Methodological manual on the work carried out by the bank employee, sector management office and coordination groups attached to the mahalla in the organization of the mahalla work system in the districts and cities. Ministry of Economic Development and Poverty Reduction, Chamber of Commerce and Industry of Uzbekistan. Tashkent, 2021
} 
What is the content and essence of the organization and development of the system of mahalla work? Today is a period of renewal, a time when work is organized on the basis of a new system, completely abandoning the usual methods of work. The effect of such reforms is to ensure that it penetrates everyone's life.

A team leader's initiative to work with specific mahallabay is the meaning of the introduction of the system. So what are the mechanisms of this system and what is its effectiveness? Let's look at the example of Samarkand region.
The total number of mahallas in the region is 1,100, with 705,350 apartments. 948,609 families live in apartment. The total population is 3918.4 thousand people.

As of March 1, 2021, there are 13,834 families registered in the "Iron Book", which includes 57,107 people. $^{4}$

34,939 women are included in the "Women's Book". The "Youth Book" includes 107,976 boys and girls. The non-permanent part of the region is $64,572,000$ people. The intersectoral distribution is as follows:

\begin{tabular}{|l|l|l|l|l|l|l|l|}
\hline № & Population & $\begin{array}{l}\text { Number of } \\
\text { neighborhood } \\
\text { citizens' } \\
\text { meetings }\end{array}$ & Apartment & $\begin{array}{l}\text { Iron } \\
\text { book }\end{array}$ & $\begin{array}{l}\text { Youth } \\
\text { book }\end{array}$ & $\begin{array}{l}\text { Women's } \\
\text { book }\end{array}$ & $\begin{array}{l}\text { families } \\
\text { without a } \\
\text { steady } \\
\text { income }\end{array}$ \\
\hline Sector 1 & 1182,9 & 395 & 232804 & 3572 & 9902 & 7458 & 18585 \\
\hline Sector2 & 722,7 & 205 & 124939 & 2991 & 7889 & 7433 & 15097 \\
\hline Sector3 & 1293,1 & 322 & 220175 & 3605 & 8904 & 523 & 19509 \\
\hline Sector4 & 719,5 & 178 & 127432 & 3666 & 8244 & 567 & 11381 \\
\hline
\end{tabular}

The connection of those responsible for the establishment of the "Mahallabay" system was carried out as follows, that is, in the three-joint system, the following persons were attached.

First joint . Permanent Representatives . 1st joint. Permanent Representatives. It consists of 774 employees of regional, district (city) commercial banks. They are permanently attached to 1,100 mahallas and have the following functions:

\footnotetext{
${ }^{4}$ Sevara Babanazarova (2020) "About ensuring a fair approach to the effective organization of the professors and teachers work.", Middle European
}

1. Studies the sources of income of the population;

2. Determines the aspirations of the unemployed population (vocational training, employment, entrepreneurship);

3. Identifies "growth points" in the neighborhood;

4. Study the efficiency and effectiveness of commissioned projects;

Scientific Bulletin, 5, pp. 88-91. doi: 10.47494 / mesb.2020.5.65 
5. Local social sector and infrastructure improvement proposals, q administrative office. ${ }^{5}$

Second joint. Management offices It consists of the heads of Finance, Treasury and Commercial Banks of the regions in 4 sectors in each city and district of the region, and is responsible for each management office and the responsible staff attached to the local economic complex. A total of 320 managers and employees are attached to these groups, including 64 management office managers. Their main functions are as follows:

1. Develops a program of socio-economic development - "Road Maps" based on the driver's areas of the neighborhood;

2. Facilitates the realization of the wishes of the unemployed population (vocational training, employment, entrepreneurship);

3. Assists in solving problems of operating business entities;

4. Implementation of new projects for the efficient use of vacant lands (auction) based on the specialization of the regions;

5. Assists the population in the allocation of loans and subsidies for the efficient use of their land;

6. Makes proposals to the coordination group on improving the social situation of the neighborhood.

Third joint. Coordinating groups. A group of 288 economic complex managers and employees led by the first deputy mayors of cities and districts. Their main tasks are:

\footnotetext{
${ }^{5}$ Ortikniyozovich, FU (2020). Theme: Forecasts And Results Of The Negative Impact Of The Covid-19 (Coronavirus) Pandemic On The World Economy And
}

1. Approves the program of socio-economic development of each mahalla.

2. The district submits the program to the local Council of Deputies and reports to the Council on a quarterly basis.

3. Considers and coordinates the activities of the management office in the presence of the chairman of the mahalla.

4. Solves problems that hinder business activities (credit and land allocation, construction permits, licensing, communication, etc.).

Local permanent representatives and management offices are provided with the following information and internal guides.

1. Survey for apartments;

2. List of families in the "Iron Book";

3. List of unemployed citizens in the "Women's Book";

4. List of unemployed citizens in the "Youth Book";

5. List of families without regular income;

6. Neighborhood growth points (drivers);

7. List of business entities operating in the neighborhood.

The following guide has been developed to provide non-permanent income to households with a stable income.

I. Allocation of subsidies to the unemployed up to 10 times the basic amount (up to 2.45 million soums): Allocation of subsidies for state registration of unemployed people wishing to do business; allocation of subsidies for entrepreneurship training;

The Economy Of Uzbekistan. The American Journal of Interdisciplinary Innovations and Research, 2 (08), 108-116. 
Allocation of subsidies for insurance policy payments when obtaining loans to entrepreneurs.

II. Vocational training - one mono-center "Welcome to work" (capacity 1545 people); KOICA training center (capacity 600 people); One vocational training center in Samarkand and Kattakurgan; 48 vocational training centers (capacity 2035 people); 16 vocational training centers (capacity 780 people); 45 nongovernmental educational institutions.

III. Vacancies and quotas - single and large children under 14 and children with disabilities; Graduates of general secondary and secondary special, vocational education; Those who have served in the mobilization reserve and have been discharged from conscription; For the disabled and people of pre-retirement age; For persons who have been subjected to coercive measures in a penitentiary institution or by a court decision; For a victim of trafficking; For individuals suffering from socially significant diseases that do not pose a risk to others.

IV. Entrepreneurship training and selfemployment - business organization, doing and running; marketing literacy; targeted lending; a set of accounting courses; labor protection; state registration.

V. Work with young people - work based on the principle of "11".

VI. Entrepreneurship lending - "Every family is an entrepreneur" program; Crafts Development Program; "Supporting Women's Entrepreneurship"; Farmers Fund.

According to the results of the census conducted by permanent representatives in the field, the total number of unemployed in the region is 183062 people.

The number of unemployed in the notebooks is 85,996 , which is distributed as follows:

The number of unemployed in the books

\begin{tabular}{|c|c|c|}
\hline & Able-bodied unemployed & $\begin{array}{c}\text { In 2021, employment will be } \\
\text { provided }\end{array}$ \\
\hline Total & 85996 & 78981 \\
\hline Iron book & 6133 & 6133 \\
\hline Youth book & 61665 & 57158 \\
\hline Women's book & 18198 & 15690 \\
\hline
\end{tabular}

Unemployed citizens can be classified according to their wishes as follows:

\begin{tabular}{|c|c|}
\hline \multicolumn{2}{|c|}{ The wishes of unemployed citizens } \\
\hline Entrepreneurship & 13479 \\
\hline Employment & 18291 \\
\hline Self-Employment & 25651 \\
\hline Vocational Training & 11916 \\
\hline
\end{tabular}


The American Journal of Interdisciplinary Innovations and Research (ISSN-2642-7478)

Published: May 31, 2021 | Pages: 112-118

Doi: https://doi.org/10.37547/tajiir/Volume03lssue05-20

\begin{tabular}{|c|c|}
\hline Work in Specialty & 5786 \\
\hline Refusal to Work & 4028 \\
\hline Public Works & 9392 \\
\hline Work Abroad & 5495 \\
\hline Uncertain & 94519 \\
\hline
\end{tabular}

In order to make the above-mentioned system of work more efficient, an ELECTRONIC PLATFORM was created, which is based on the following scheme.

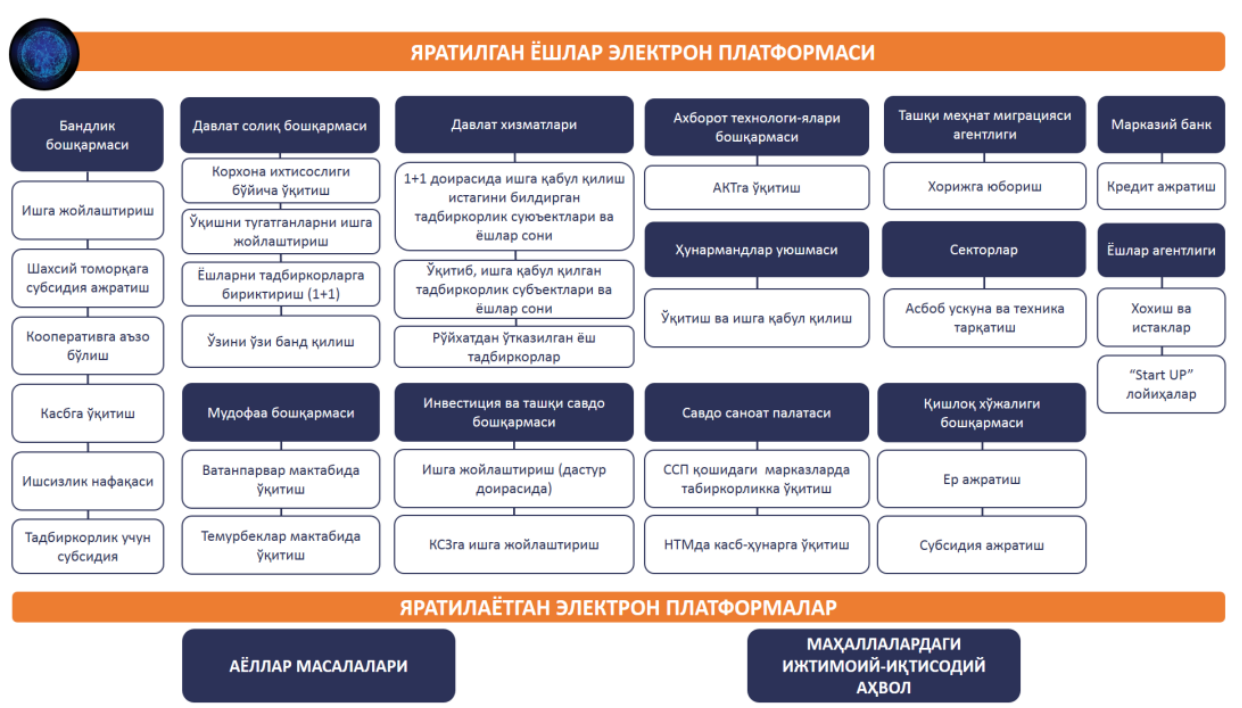

Today, the number of households without a permanent source of income is 64,572 . Of which:

The number of those wishing to work in existing enterprises is 5172 ;

16729 expressed interest in entrepreneurship; 11,285 people applied for loans.

It should be noted that on April 15-16, 2021, President Sh. Mirziyoyev visited Samarkand region and at a meeting with activists and heads of industries spoke about the "Samarkand experience" of the "Mahallabay" system. In the new system, the
Mahallabay Work Center will be established in the structure of the first deputy mayor of the district, the city will have one inspector in each of the three mahallas. was reported to be engaged in a constant.

\section{CONCLUSIONS AND SUGGESTIONS}

In 2021, the Uzbek economy is expected to grow by at least $5 \%$. However, the uncertainty in the global economy that can persist for a long time requires finding and mobilizing additional resources for economic growth.

Therefore, leaders at all levels are tasked with studying the situation in the community in their 
field, identifying "growth points" and developing them. This led to the creation of a system of self-employment.

The Mahallabay operating system is a new system, which, although not yet in history, is one of the economic models. Creating a theoretical and methodological basis for it is a topical issue.

Although the Mahallabay system does not solve all problems at once in some places, it is seen as an optimal mechanism for solving some problems faster and achieving results.

In order to develop cities and districts in the mahalla system, it is expedient to coordinate the activities and increase the efficiency of the management offices established in each sector, consisting of qualified employees of the economic complex.

To do this, it is necessary to conduct a complete inventory of the situation of the needy population in each neighborhood and to organize accounting and control over its implementation at the required level. This is because the exchange of information between permanent representatives, management offices and coordination groups, there are some shortcomings in the reporting mechanism.

\section{REFERENCES}

1. Methodological manual on the work carried out by the bank employee, the sector management office and the coordination groups attached to the mahalla in the organization of the mahalla work system in the districts and cities.
Ministry of Economic Development and Poverty Reduction, Chamber of Commerce and Industry of Uzbekistan. Tashkent, 2021.24 p.

2. Neighborhood processing system. Uzbekistan 24 TV channels. Analysis. March 4, 2021.

3. Neighborhood processing system. Uzbekistan 24 TV channels. Analysis. March 4, 2021.

4. Sevara Babanazarova (2020) "About ensuring a fair approach to the effective organization of the professors and teachers work.", Middle European Scientific Bulletin, 5, pp. 88-91. doi: 10.47494/mesb.2020.5.65.

5. Ortikniyozovich, F. U. (2020). Theme: Forecasts And Results of The Negative Impact Of The Covid-19 (Coronavirus) Pandemic On The World Economy And The Economy of Uzbekistan. The American Journal of Interdisciplinary Innovations and Research, 2(08), 108-116.

6. Expensive mechanism or temporary effect. Thoughts on the neighborhood performance system. Uzbekistan TV channel. Daily news. March 2, 2021.

7. Sevara Babanazarova (2020) "About ensuring a fair approach to the effective organization of the professors and teachers work.", Middle European Scientific Bulletin, 5, pp. 88-91. doi: 10.47494/mesb.2020.5.65. 